\title{
Isolation of a previously undescribed rhabdovirus from pike Esox lucius
}

\author{
P. E. V. Jørgensen ${ }^{1}$, N. J. Olesen ${ }^{1}$, W. Ahne ${ }^{2}$, T. Wahli ${ }^{3}$, W. Meier ${ }^{3}$ \\ ${ }^{1}$ National Veterinary Laboratory, Hangøvej 2, DK-8200 Århus N, Denmark \\ ${ }^{2}$ Institut für Zoologie und Hydrobiologie, Universität München, Kaulbachstraße 37, D-80539 München, Germany \\ ${ }^{3}$ Untersuchungsstelle für Fischkrankheiten, Institut für Tierpathologie, Universităt Bern, Länggaßstraße 122, \\ Bern, Switzerland
}

\begin{abstract}
During virological examination of healthy pike fry, a rhabdovirus, probably belonging to the Vesiculo group of the rhabdovirus family, was isolated which appeared to be distinct from 12 other fish rhabdoviruses. The virus shared antigenic sites with perch rhabdovirus as shown by indirect immunofluorescence techniques. The virus was strongly pathogenic for pike fry but not for raınbow trout fry under aquarium conditions. Histopathological changes in pike fry exposed to bath infection with the virus showed haemorrhages and tissue necrosis resembling the changes induced by viral haemorrhagic septicaemia virus and other rhabdoviruses causing systemic infections.
\end{abstract}

\section{INTRODUCTION}

In June 1989, virological examination was performed on a population of apparently healthy, $5 \mathrm{~cm}$ long pike Esox lucius fry suspected of having been exposed to Egtved virus, the causative agent of viral haemorrhagic septicaemia (VHS) (Jensen 1965), via the water from a trout farm with a rainbow trout Oncorhynchus mykiss population suffering from an acute outbreak of VHS.

The fry originated from eggs and sperm from populations of free-living pike in the lakes Nords Sø and Stubbegard $\mathrm{S} \emptyset$ in the northern part of Jutland, Denmark. They were hatched and reared in tap water in a private aquaculture unit on the island of Mors until approximately $3 \mathrm{wk}$ postspawning, at which time they were transferred to net cages in Hjarbæk Fjord and Stubbegård Sø. The fry had spent $4 \mathrm{wk}$ in the net cages when a pooled sample was collected from the 2 sites for virological examination. At the time of sampling no signs of disease were observed.

The pike were fed Daphnia spp. harvested in Hjarbæk Fjord. The aquaculture unit simultaneously hatched and reared fry of white fish Coregonus sp. and these were also virologically examined.

During the virological examination of the pooled sample of pike fry, a virus was isolated which appeared to be different from other viruses isolated from fish. The present work describes some basic characteristics of this virus

\section{MATERIAL AND METHODS}

Cultivation of cells. The BF-2 (Wolf et al. 1966), EPC (Fijan et al. 1983), FHM (Gravell \& Malsberger 1965), RTG-2 (Wolf \& Quimby 1962), CHSE (Lannan et al. 1984, CLC (Faisal \& Ahne 1990), BB (Wolf \& Quimby 1969), PG (Ahne 1979) and R1 (Ahne 1985) cell lines were cultivated in Eagles MEM with $10 \%$ foetal bovine serum, penicillin (100 $\mathrm{IU} \mathrm{ml}^{-1}$ ) and streptomycin $\left(100 \mu \mathrm{g} \mathrm{ml}^{-1}\right)$. In tissue culture flasks the medium was buffered with bicarbonate, in open cell culture systems the medium contained an organic buffer (Tris). Incubation temperatures during outgrowth of cells varied between $20^{\circ}$ and $28^{\circ} \mathrm{C}$ depending on the cell line.

Virological examination. Pike Esox lucius fry were virologically examined as previously described (Olesen \& Jørgensen 1992). Briefly, fry were minced with scissors, homogenized with quartz sand, diluted $1: 5$ in cell culture medium and, following removal of 
organ debris by centrifugation at $3000 \times g$ for $15 \mathrm{~min}$ at $4{ }^{\circ} \mathrm{C}$, incubated with antibiotics overnight at $4^{\circ} \mathrm{C}$ and then inoculated into BF-2 cell cultures at final dilutions of $1: 50,1: 500$ and $1: 5000$.

Inoculated cultures were incubated at $15^{\circ} \mathrm{C}$ and examined daily for cytopathic effects (CPE). Virus identification of the isolate DK 5533 was performed by means of neutralization and immunofluorescence tests as previously described (Jorgensen 1974).

Production of antiserum to virus isolate DK 5533 from pike. Virus produced in BF-2 cells was gradient purified and used for immunization of rabbits as previously described (Olesen et al. 1991). The antiserum was tested by immunofluorescence against a number of rhabdoviruses isolated from fish, since electron microscopy at an early stage of the study indicated that the virus isolate had a rhabdovirus morphology. Other antisera used, either produced locally or obtained from other laboratories, are listed in Table 1.

Virus isolates. The identity and origin of the virus isolates used are shown in Table 1 . The virus strains were stored at $-80^{\circ} \mathrm{C}$ as filtered $(0.45 \mu \mathrm{m}$ pore-size membranes) tluids from infected BF-2 or EPC cells according to the cell culture preference of each of the viruses.

Titration of virus. Virus was titrated by the $50 \%$ end-point dilution $\left(\mathrm{TCID}_{50}\right.$ : tissue culture infective dose) method in BF-2 and CLC cells grown in microculture at $20^{\circ} \mathrm{C}$. Infectivity of virus was calculated by the method of Reed \& Muench (1938).

Determination of cell line preference. To investigate the cell culture spectrum of the virus, $\mathrm{BB}, \mathrm{BF}-2$, CHSE-214, EPC, FHM, PG, R1 and RTG-2 cells were infected at a multiplicity of infection (MOI) of 0.1 . After $7 \mathrm{~d}$ at $20^{\circ} \mathrm{C}$ flasks were frozen at $-70^{\circ} \mathrm{C}$, thawed and the cell-free medium was titrated in $\mathrm{BF}-2$ cells

Determination of temperature optimum. The optimum temperature for virus replication was determined using CLC cells grown in $25 \mathrm{~cm}^{2}$ flasks. The cells were infected at a MOI 0.1, and incubated at 10, 15, 20, 25, and $30^{\circ} \mathrm{C}$. After $7 \mathrm{~d}$ infected cell cultures were frozen at $-70^{\circ} \mathrm{C}$, thawed and the cell-free medium titrated by the TCID 50 method.

Absorption of antisera. Before use in immunofluorescence tests, most of the viral antisera were absorbed as follows: 1 flask $\left(75 \mathrm{~cm}^{2}\right)$ of EPC cells and 1 flask of BF-2 cells were treated with a Trypsin-Versene solution to detach the cells. The cells were pelleted by centrifugation at $1000 \times g$ for 5 min, resuspended in phosphate-buffered saline (PBS), centrifuged again and finally resuspended in $4 \mathrm{ml}$ of a 1:50 dilution of antiserum in cell culture medium. The suspension was incubated overnight at $4^{\circ} \mathrm{C}$ with constant agitation, centrifuged at $3000 \times g$ for $15 \mathrm{~min}$ and filtered through a $0.45 \mu \mathrm{m}$ pore size membrane filter
With antisera against VHSV, infectious hematopoietic necrosis virus (IHNV), carpione brown trout virus and thabdovirus 903/87, partial purification of immunoglobulin (Ig) was performed by affinity chromatography on Protein A-Sepharose (Pharmacia) according to the suppliers instructions before the cell absorption step in order to further reduce background staining.

Immunofluorescence tests. Coverglass cultures of BF-2 and EPC cells were inoculated with the virus strains at concentrations which would give rise to 0.5 to 3 plaques per microscopic field when stained with homologous antiserum at a selected incubation time.

Occasionally cultures were used which contained a maximum of $50 \%$ positively stained cells. The incubation time with most of the virus strains was $24 \mathrm{~h}$ but was longer for IHNV (48 h), eel rhabdovirus (B-12) $(144 \mathrm{~h})$, and ulcerative disease rhabdovirus (UDRV) (96 h). The incubation temperature was $15^{\circ} \mathrm{C}$ except for UDRV $\left(20^{\circ} \mathrm{C}\right)$.

Coverglass cultures were rinsed, fixed in acetone and immunologically stained for immunofluorescence as previously described (Jørgensen et al. 1989) using dilutions of rabbit serum in the first reagent layer and rhodamine-conjugated swine antibodies to rabbit immunoglobulin (Dako, Copenhagen, Denmark) as the second reagent layer.

Optimal dilutions of the rabbit antibodies in the first reagent layer were determined against homologous virus for each of the antisera used. The optimal dilutions, made in cell culture medium, ranged between $1: 25$ and 1:800. The secondary antibodies were routinely applied at a 1:100 dilution in cell culture medium.

Electron microscopy. CLC cells were infected at a MOI of 0.1 and incubated for $72 \mathrm{~h}$ at $20^{\circ} \mathrm{C}$. Cells were then fixed in $2.5 \%$ glutaraldehyde in $0.067 \mathrm{M}$ Sørensen-phosphate buffer $(\mathrm{pH} 7.4)$ for $2 \mathrm{~h}$, washed 3 times with $0.2 \mathrm{M}$ D+-saccharose-Sørensen-phosphate buffer and postfixed with $1 \%$ osmium tetroxide in $0.1 \mathrm{M}$ cacodylate buffer for $2 \mathrm{~h}$. After dehydration in a graded acetone series, the specimens were embedded in Epon 812. Semithin sections were stained with $1 \%$ toluidine blue in $1 \%$ borax. Ultrathin sections stained with uranyl acetate and lead citrate were examined using a transmission electron microscope (Zeiss EM 109). A negatively-stained $(0.1 \%$ phosphotunstic acid) virus pellet $(85000 \times \mathrm{g}, 2 \mathrm{~h})$ was examined as well.

Sodium dodecyl sulphate polyacrylamide gel electrophoresis (SDS-PAGE). SDS-PAGE was performed according to the method of Laemmli (1970) in $0.75 \mathrm{~mm}$ slab gels using a vertical system. The stacking gel contained $3.5 \%$ acrylamide $/ 0.11 \%$ bisacrylamide, and the separating gel $10 \% / 0.31 \%$. Molecular weight standards from Kem-En Tec (Hellerup, Denmark) were in- 


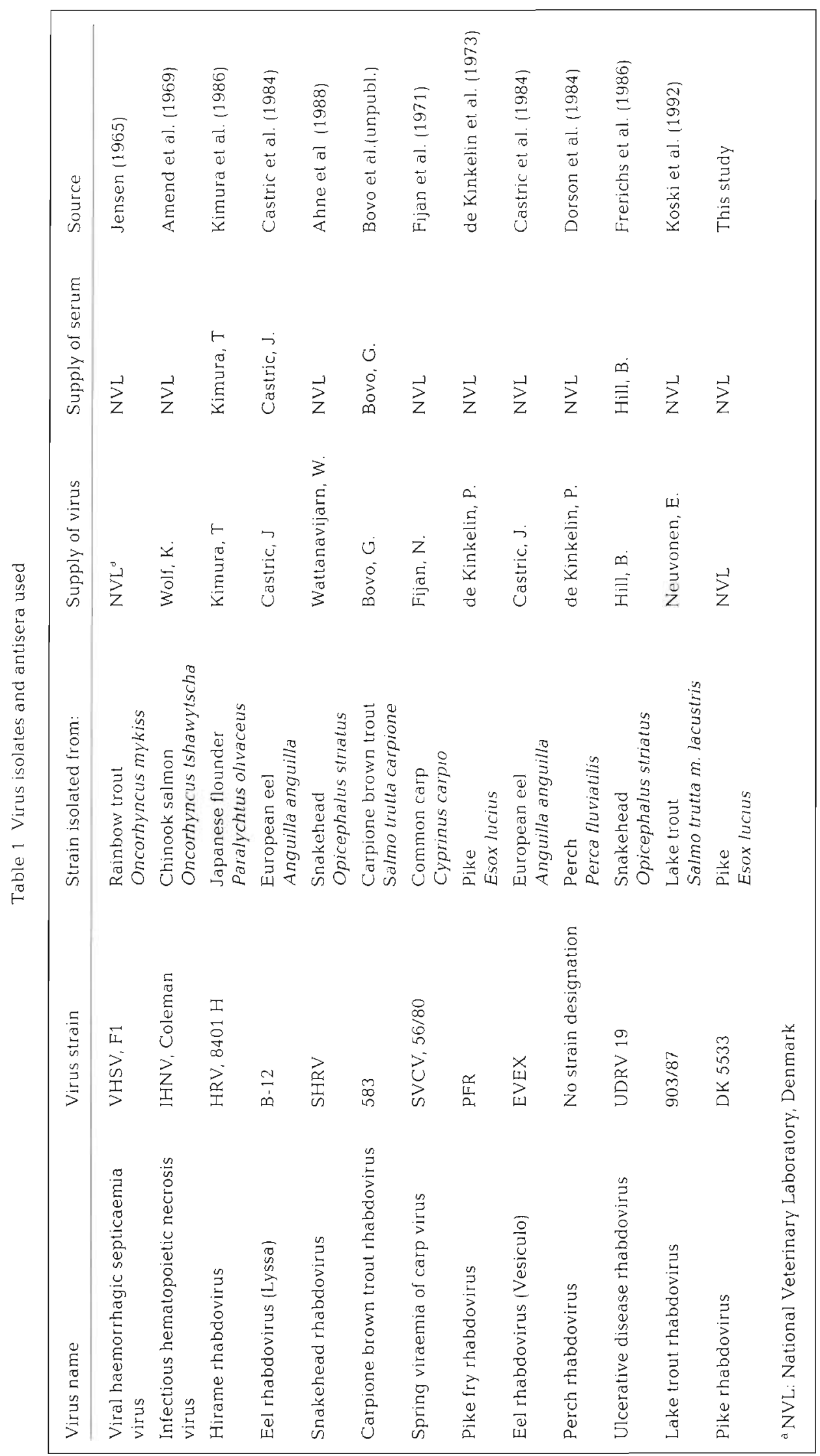




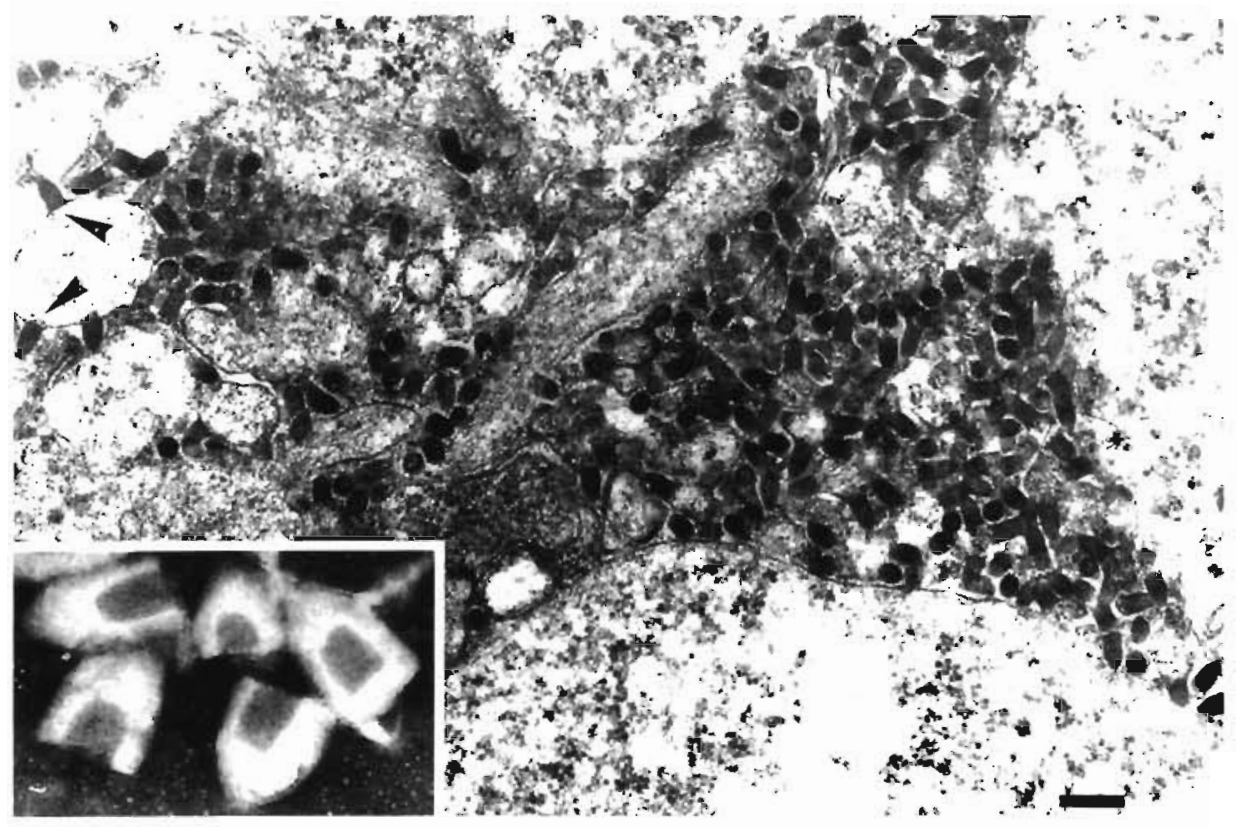

Fig. 1. Electron micrograph of an infected CLC cell showing bullet-shaped virus particles in the cytoplasm. Budding process (arrow wheads). Scale bar $=200$ $\mathrm{nm}$. Inset: negatively stained virus particles $(265000 \times)$ cluded in each run. Silver staining was performed as described by Morrissey (1981).

Experimental infection. Pike fry $(2.5$ to $3.5 \mathrm{~cm}$ fork length) and rainbow trout fry (4 to $5 \mathrm{~cm}$ fork length) were obtained from a spring-water-supplied hatchery, repeatedly testing free of viral infections. The fish were acclimated for $7 \mathrm{~d}$ prior to the infection and were fed fresh plankton daily during the entire experimental period. The tap-water-supplied tanks (200 l) were divided into 2 equal compartments by a mesh. The temperature was $14.8 \pm 0.3^{\circ} \mathrm{C}$. The fish were infected with virus by bath exposure at concentrations of $10^{2}, 10^{3}$, $10^{4}$ and $10^{5} \mathrm{TCID}_{50} \mathrm{ml}^{-1}$ of water for $60 \mathrm{~min}$ at $14.5^{\circ} \mathrm{C}$. The treated fish were transferred to the abovementioned tanks with 100 pike fry on one side of the mesh and 50 rainbow trout fry on the other. Control fish were exposed to an equal volume of virus-free PBS and handled as the infected groups.

Histopathological examination. Organs and tissue samples were fixed in Bouin's solution ( $\mathrm{pH} 7.4$ ) for histology. Thereafter, the tissue was embedded in paraffin wax and 4 to $6 \mu \mathrm{m}$ sections were cut and stained with haematoxylin and eosin (H \& E).

\section{RESULTS}

Four days after inoculation of BF-2 cell cultures with tissue material from the pike, extensive CPE was evident. The CPE persisted during subsequent passages of membrane-filtered cell culture fluid in BF-2 cells. The virus isolate (DK 5533) was not neutralized during routine neutralization tests with antisera to infections pancreatic necrosis virus (IPNV), VHSV or IHNV. The virus was sensitive to chloroform and exhibited the bullet-shape morphology typical of rhabdoviruses. The dimensions of the virus particles were $60 \mathrm{~nm}( \pm 10 \mathrm{SD})$ in diameter and $120 \mathrm{~nm}( \pm 10 \mathrm{SD})$ in length (average of the dimensions of 10 individual particles) (Fig. 1). SDSPAGE showed that the virus proteins had molecular weights of approximately $62(\mathrm{G}), 51\left(\mathrm{~N}_{\mathrm{s}}\right), 45(\mathrm{~N})$ and 27 (M) kd respectively. Interpretation of the migration pattern of the proteins (Fig. 2), as suggested by Castric et al. (1984), indicated that the virus may belong to the Vesiculo-rather than the Lyssa group of Rhabdoviridae (McAllister \& Wagner 1975).

In immunofluorescence tests, Isolate DK 5533 was intensively stained by homologous antiserum as well as by antiserum to perch rhabdovirus. Staining by antisera to 11 other rhabdoviruses was not observed. Conversely, the antiserum to DK 5533 induced a brilliant staining not only of homologous virus but also of perch rhabdovirus. In addition a weak staining of Isolate 903/87 was observed.

Positive reactions appeared as brilliant cytoplasmic staining of a fine granular type as described for other fish rhabdoviruses such as VHSV (Jørgensen \& Meyling 1972) or spring viraemia of carp virus (SVCV) and pike fry rhabdovirus (PFR) (Jørgensen et al. 1989). Highest yields of infectious virus were obtained in CLC and BF-2 cells (Table 2). RTG-2, EPC and CHSE214 cells appeared to be refractory to the virus. Temperature optimum for virus multiplication was $20^{\circ} \mathrm{C}$; multiplication also occurred at 10,15 and 25 , but not at $30^{\circ} \mathrm{C}$. The maximal yield of virus was $10^{7.5} \mathrm{TCID}_{50}(0.1 \mathrm{ml})^{-1}$ at $20^{\circ} \mathrm{C}$. 


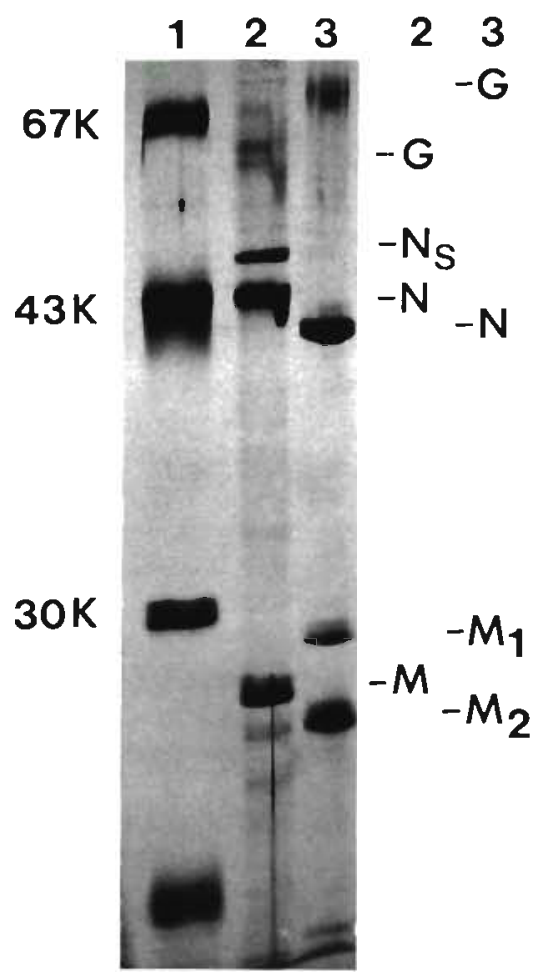

Fig. 2. Electropherogram of purified virus preparations in SDS-PAGE. Lane 1: Molecular weight markers; Lane 2: Eel rhabdovirus EVEX (vesiculo group); Lane 3: VHSV (lyssa group); Lane 4: DK 5533 from pike. The localization of the structural proteins $G, N S, N$ and $M$ (lanes 2 and 4 ) and G, N, M1 and M2 (lane 3), respectively, is indicated. The protein band of about $22 \mathrm{KD}$ in lane 4 is considered to be a degradation product of the $\mathrm{M}$ protein, since it appeared only after prolonged storage of the purified virus

The infection experiments showed that the pike virus was pathogenic for pike fry at a concentration of $10^{5} \mathrm{TClD}_{50} \mathrm{ml}^{-1}$ and caused a cumulative mortality of $87 \%$ after $11 \mathrm{~d}$. At $10^{2} \mathrm{TCID}_{50} \mathrm{ml}^{-3}$, a modest mortality of $6 \%$ was observed (Fig. 3).

The onset of mortality in pike occurred between Day 3 \& 5 postinfection. Affected pike were apathetic and floated on their side on the surface or remained motionless at the bottom of the aquarium. Most of the pike with symptoms died within $24 \mathrm{~h}$. Swelling with haemorrhages in the trunks, breast and tail fins were the most typical findings. Haemorrhages in the head region and other parts of the body surface were observed less often. A slight bilateral exophthalmus was frequently seen. The gills were extremely pale and the abdomen was filled by a clear, slightly yellow-
Table 2. Yield $\left[\log _{10} \mathrm{TCID}_{50}(0.1 \mathrm{ml})^{-1}\right]$ of virus (DK 5533) in various fish cell lines

\begin{tabular}{|lc|}
\hline Cell line & Yield \\
\hline CLC & 5.8 \\
BF-2 & 5.5 \\
BB & 4.8 \\
FHM & 3.2 \\
PG & $<1$ \\
R1 & $<1$ \\
RTG-2 & 0 \\
EPC & 0 \\
CHSE-214 & 0 \\
\hline
\end{tabular}

ish, sometimes haemorrhagic fluid. The liver was pale, the spleen enlarged and the contents of the intestine interspersed with a milky slime. Retroperitoneally focal haemorrhages were present around the kidney and in a striated form scattered throughout the musculature (Fig. 4).

In addition to a generalized edema, a distinct hydropericard was regularly seen and adherent single or groups of mononuclear cells were observed on the endocard. Scattered, single cell degenerations, focally pronounced along the dilated sinusoids, were found in the liver. The most significant changes were observed in the anterior kidney and the renal tubules. These changes included necrotic foci, degeneration of individual cells in the haematopoietic part and selective damage of the capillary endothelium with focal adherence of mononuclear cells (Figs. 5 \& 6)

Focal necrosis was also detectable in the liver and the spleen. The renal tubules, irregularly swollen, partly collapsed or even destroyed, contained hyaline casts or necrotic material. Many epithelial cells, focally

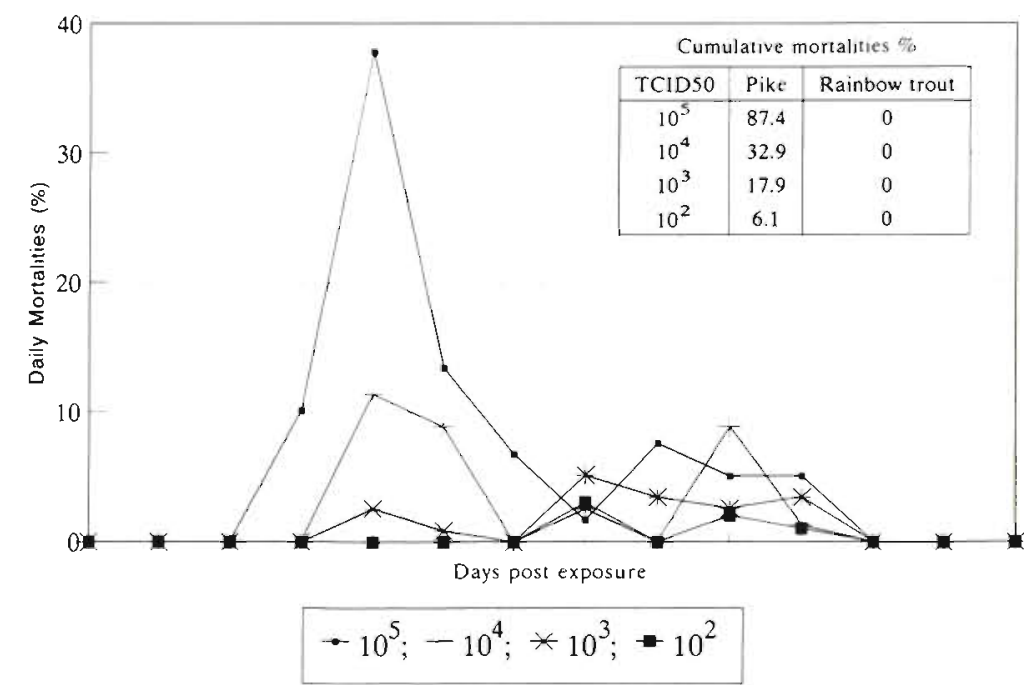

Fig. 3. Mortality in pike and rainbow trout fry following exposure to bath infection with different infection doses of the isolate DK 5533 


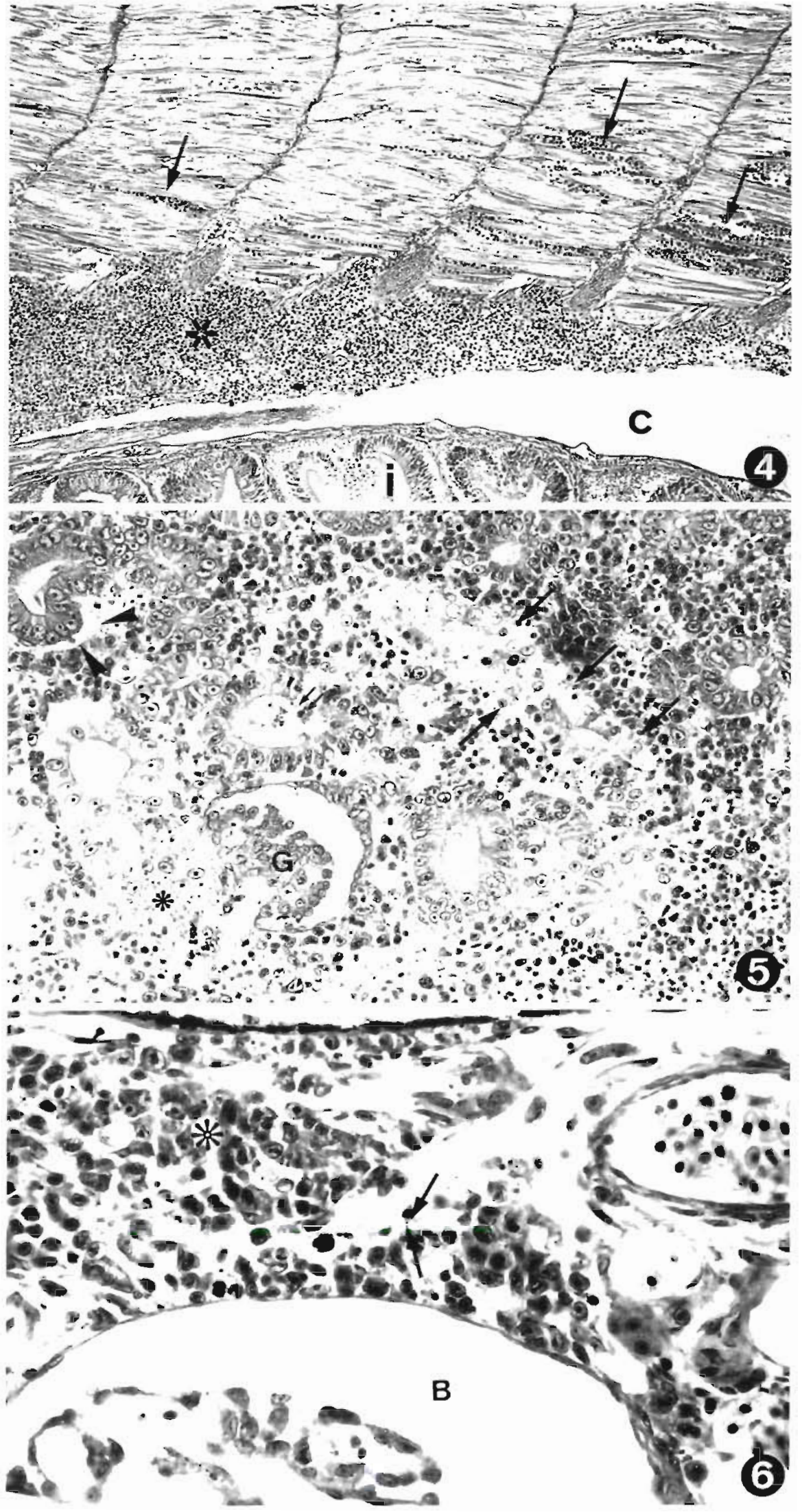

Figs. 4 to 6. Esox lucius. Fig. 4. Focal retroperitoneal haemorrhages $(*)_{i}$ scattered intermuscular haemorrhages (arrows); $i$, intestine; $c$, abdominal cavity $(H \& E, \times 290)$. Fig. 5. Highly damaged kidney with different stages of tubular changes; destroyed tubule (large arrows), tubules with degenerated epithelial cells $(*)$ and necrotic cells and debris in the lumen (small double arrows), partly detached epithelral cells (arrowheads). Glomerulum (G) with slightly swollen mesangium and enlarged Bowmans space (H\&E, 725×). Fig. 6. Destroyed capillary endothelium (arrows) and necrotic cells and debris in the interstitial part of the kidney (*); glomerulum with enlarged Bowmans space (B) $(H \& E, 1160 \times)$ 
detached from the basal membrane, often had hyperchromatic, swollen or pycnotic nuclei and their borders became unrecognizable (Fig. 5). Finally, a slightly swollen mesangium together with an enlarged Bowmans space appeared to be the most dominant glomerular finding (Fig. 6)

The virus did not induce disease signs or mortality in rainbow trout, but virus was isolated from some of the trout samples taken for virological examination during the second and third week postinfection even among the fish exposed to the lowest virus concentration. Virus isolated from diseased experimental pike gave the same reaction pattern in immunofluorescence tests as the original isolate.

No virus was isolated from the white fish which had been kept in close proximity to the pike fry from which the virus was originally isolated. VHSV was not isolated from either of the 2 species despite the waterborne exposure which was known to have taken place.

\section{DISCUSSION}

The results presented here indicate that the DK 5533 isolate is a rhabdovirus distinct from 12 other rhabdoviruses previously isolated from fish, although it shares antigenic determinants with perch rhabdovirus and also, to a small extent, with Isolate 903/87 from lake trout. Antigenic relationships with other fish rhabdoviruses were not observed.

The following characteristics separate DK 5533 from perch rhabdovirus: (1) the dimensions of the DK 5533 virus particles were $120 \times 60 \mathrm{~nm}$ as opposed to the $200 \times 100 \mathrm{~nm}$ published for perch rhabdovirus particles (Dorson et al. 1984); (2) unlike perch rhabdovirus, DK 5533 did not multiply in RTG-2 cells; (3) DK 5533 was highly pathogenic to its 'host' species, pike, whereas perch rhabdovirus was pathogenic to perch only by intracranial injection (whether perch rhabdovirus might be more pathogenic to pike than to perch remains to be seen); (4) DK 5533 under experimental conditions causes a haemorrhagic disease, whereas perch rhabdovirus causes nervous signs without haemorrhages.

The authors are aware that published information exists about 2 additional fish rhabdoviruses, which unfortunately were not available from any known sources. For this reason Rio Grande cichlid rhabdovirus isolated from Cichlasoma cyanoguttatum (Malsberger \& Lautenslager 1980) and Rhabdovirus salmonis isolated from rainbow trout in the Soviet Union (Osadchaya \& Nakonechnaya 1981) could not be included in the study. The serological relationship between these 2 viruses and the rhabdoviruses used in the present study remains unknown. For the sake of completeness it deserves mentioning that the eel virus 'American' (EVA) from American eel Anguilla rostrata (Sano et al. 1976) is antigenically indistinguishable from the eel virus 'European' (EVEX) from European eel Anguilla anguilla examined in the present study (Hill et al. 1980) and that cod ulcus syndrome rhabdovirus (Jensen et al. 1979) similarly has been found to be serologically indistinguishable from VHSV (Jørgensen \& Olesen 1987). A recently isolated rhabdovirus from pike perch Stizostedion lucioperca (Nougayrede et al 1992) was found to be antigenically related to the perch rhabdovirus described by Dorson et al. (1984). Due to their well-documented antigenic similarity with other rhabdoviruses, the latter 3 viruses were not included in the study. The reason for including 2 rhabdoviruses from snakehead in the study was that initial studies (authors's unpubl. results) had shown that the isolate (snakehead rhabdovirus, SHRV) received from Dr Wattanavijarn, Bangkok, Thailand (Ahne et al. 1988) was serologically distinct from the UDRV-19 isolate received from the United Kingdom. The existence of this difference between rhabdovirus isolates from snakehead has recently been confirmed in another laboratory (Kasornchandra et al. 1992) comparing an SHRV isolate, also obtained from Dr Wattanavijarn, with UDRV-19 obtained from Dr Frerichs, Stirling, UK

Although no signs of disease were observed in the spontaneously infected pike fry, the results from the infection trial indicate that the virus is pathogenic to pike fry at moderate to high concentrations under bathinfection conditions.

The clinical course of the experimental disease, the signs of disease, and the gross and histological findings in the examined pike were largely as observed in the acute form of VHS of pike (Meier \& Pfister 1981). The most prominent changes were evident in the kidney with alterations of the tubule structures and the capillary endothelia.

However, all changes were of a nonspecific degenerative character as described for VHS infections in white fish (Meier et al. 1986) and grayling (Meier \& Wahli 1988) and for pike fry rhabdovirus disease in pike (Bootsma 1971).

Judging from the experimental infection experiments, the virus from pike was nonpathogenic for rainbow trout, but appeared capable of multiplying at a low level in bath-infected rainbow trout fry. Whether the virus is pathogenic for pike or other fish species under aquaculture conditions is unknown at present.

On the basis of the present preliminary results it appears worth while to study in more detail the antigenic relationship between DK 5533, perch rhabdovirus pike perch rhabdovirus and Isolate 903/87 from lake trout, e.g. by Western blotting. Such a study would reveal to what extent the viruses share antigenic deter- 
minants on their structural proteins, and thus clarify whether or not the viruses should be grouped together in a separate group of serologically related rhabdoviruses. Similarly, comparative pathogenicity studies involving young fish of all the involved 'host' species, i.e. pike, perch, pike perch and lake trout would be of considerable interest

Acknowledgements. Thanks are due to the following persons for generously supplying virus and/or antiserum: Dr K. Wolf, formerly of the National Fish Health Research Laboratory, Leetown, USA, Dr N. Fijan, formerly of the University of Zagreb, Zagreb, Croatia, Dr Barry Hill, Fish Disease Laboratory, Weymouth, UK, Dr Jeanette Castric, Centre National d'Etucles Vétérinaires et Alimentaires, Brest, France, Dr P. de Kinkelin, Institut National de la Recherche Agronomique, Jouy-en-Josas, France, Dr T. Kimura, University of Hokkaido, Hakodate, Japan, Dr E. Neuvonen, National Veterinary Institute, Helsinki, Finland, Dr G. Bovo, Istituto Zooprofilattico Sperimentale delle Venezie, Padova, Italy and Dr W. Wattanavijarn, Chulagongkorn University, Bangkok, Thailand.

\section{ADDENDUM}

After termination of the present study, a virus (Vi 2007/91/2) isolated from white fish Coregonus lavaretus S.L. in Finland (E. Neuvonen, National Veterinary Institute, Helsinki, Finland, pers. comm.) was identified at the National Veterinary Laboratory, Arhus, Denmark, as being very similar to the presently identified isolate DK 5533 from pike in immunofluorescence tests with the described panel of reagents

\section{LITERATURE CITED}

Ahne, W. (1979). Fish cell culture: a fibroblastic cell line (PG) from ovaries of juvenile pike (Esox lucius). In Vitro 15 $839-840$

Ahne, W (1985). Untersuchungen über die Verwendung von Fischzellkulturen für Toxizitätsbestimmungen zur Einschränkung und Ersatz des Fischtests. Zbl. Bakt. Hyg. Abt. I.: Orig. B, 180:480-504

Ahne, W., Jergensen, P. E. V., Olesen, N. J., Wattanavijarn, W. (1988). Serological examination of a rhabdovirus isolated from snakehead (Ophicephalus striatus) in Thailand with ulcerative syndrome. J. appl. Ichthyol. 4: 194-196

Amend, D. F., Yasutake, W. T. Mead, R. W. (1969). A hematopoietic virus disease of rainbow trout and sockeye salmon. Trans. Am. Fish. Soc. 98: 796-804

Bootsma, R. (1971). Hydrocephalus and red-disease in pike fry Esox lucius L. J. Fish. Biol. 3: 417-419

Castric, J., Rasschaert, D., Bernard, J. (1984). Evidence of lyssaviruses among rhabdovirus isolates from the European eel (Anguilla anguilla). 135E: 35-55

de Kinkelin, P., Galimard, B., Bootsma, P. (1973). [solation and identification of the causative agent of 'red disease' of pike (Esox lucius L. 1766). Nature 241: 465-467

Dorson, M., Torchy, C., Chilmonczyk, S., de Kinkelin, P., Michel, C. (1984). A rhabdovirus pathogenic for perch (Perca fluviatilis L.): isolation and preliminary study. J. Fish Dis. 7: 241-245

Faisal, M., Ahne, W. (1990). A cell line (CLC) of adherent peripheral blood mononuclear leucocytes of normal common carp (Cyprinus carpio). Dev. comp. Immunol. 14: 255-260
Fijan, N., Petrinec, Z., Sulimanovic, D., Zwillenberg, L. O. (1971). Isolation of the viral causative agent from the acute form of infectious dropsy of carp. Vet. Arh 41 $125-135$

Fijan, Ni., Sulimanovic, D., Bearzotti, M., Muzinik, D., Zwillenberg, L. O., Chilmonczyk, S., Vautherot, J. F., de Kinkelin, P. (1983). Some properties of the epithelioma papulosum cyprini (EPC) cell line from carp (Cyprinus carp10). 134E: $207-220$

Frerichs, G. N., Milar, S. D., Roberts, R. J. (1986). Ulcerative rhabdovirus in fish in Southeast Asia. Nature 322: 216

Gravell, M. Malsberger, R. G. (1965). A permanent cell line from the fathead minnow (Pimephales promelas). Ann. N.Y. Acad. Sci. 126: 555-565

Hill, B. J., Williams, R. F., Smale, C. J., Underwood, B. O., Brown, F. (1980). Physicochemical and serological characterization of two rhabdoviruses isolated from eels. Intervirology 14: 208-212

Jensen, M. H. (1965). Research on the virus of Egtved disease. Ann. N.Y. Acad. Sci. 1.26: 422-426

Jensen, N. J., Bloch, B., Larsen, J. L. (1979). The ulcus syndrome in cod (Gadus morhua). IH. A preliminary virological report. Nord. Vet.-Med. 31: 436-422

Jørgensen, P. E. V. (1974). A study of viral diseases in trout. Their diagnosis and control. Ph.D. thesis, Royal Veterinary and Agricultural University, Copenhagen

Jørgensen, P. E. V., Meyling, A. (1972). Egtved virus: demonstration of virus antigen by the fluorescent antibody technique in tissues of rainbow trout affected by viral haemorrhagic septicaemia and in cell cultures infected with Egtved virus. Arch. ges. Virusforsch. 36: 115-122.

Jørgensen, P. E. V., Olesen, N. J. (1987). Cod ulcus syndrome rhabdovirus is indistinguishable from Egtved virus (VHS) virus. Bull. Eur. Ass. Fish Pathol. 7: 73-74

Jorgensen, P. E. V., Olesen, N. J., Ahne, W., Lorenzen, N. (1989). SVCV and PFR viruses: serological examination of 22 isolates indicates close relationship between the two fish rhabdoviruses. In: Ahne, W., Kurstak, E. (eds.) Viruses of lower vertebrates. Springer Verlag, Berlin, p. $349-366$

Kasornchandra, J., Engelking, H. M., Lannan, C. N., Rohovec, J. S., Fryer, J. L. (1992). Characteristics of three rhabdoviruses from snakehead fish Ophicephalus striatus. Dis. aquat. Org. 13: 89-94

Kimura, T., Yoshimizu, M. Gorie, S. (1986). A new rhabdovirus isolated in Japan from cultured hirame (Japanese flounder) (Paralichthys olivaceus) and ayu (Plecoglossus altivelis). Dis. aquat. Org. 1: 209-217

Koski, P., Hill, B. J., Way, K., Neuvonen, E., Rintamäki, P. (1992). A rhabdovirus isolated from brown trout (Salmo trutta $m$. lacustris (L)) with lesions in parenchymatous organs. Bull. Eur. Ass. Fish Pathol 12:177-180

Laemmli, U. K. (1970). Cleavage of structural proteins during assembly of the head of bacteriophage T4. Nature 227 : $680-685$

Lannan, C. N., Winton, J. R., Fryer, J. L. (1984). Fish cell lines: establishment and characterization of nine cell lines from salmonids. In Vitro 20:671-676

Malsberger, R. G, Lautenslager, G. (1980). Fish viruses: rhabdovirus isolated from a species of the family Cichlidae Fish Health News 9 no. 2, i-ii

McAllister, P. E., Wagner, R. R. (1975). Structural proteins of two salmonid rhabdoviruses. J. Virol. 15: 733-38

Meier, W., Ahne, W., Jørgensen, P. E. V. (1986). Fish viruses viral haemorrhagic septicaemia in white fish (Coregonus sp.). J. appl. Ichthyol. 2: 181-186

Meier, W., Pfister, K. (1981). Viral haemorrhagic septicaemia 
(VHS) in pike (Esox lucius L): clinical, macroscopic, histological and electron-microscopical findings: direct visualization of Egtved virus. Schweiz. Arch. Tierheilkde. 123: $37-49$

Meier, W., Wahli, T (1988). Viral haemorrhagic septicaemia (VHS) in grayling (Thymallus thymallus L.). J Fish Dis 11: $481-487$

Morrissey, J. H. (1981). Silver stain for proteins in polyacrylamide gels: a modified procedure with enhanced unjform sensitivity. Analyt. Biochem. 117: 307-310

Nougayrede, P., de Kinkelin, P., Chilmonczyk, S., Vuillaume, A. (1992). Isolation of a rhabdovirus from the pike-perch [Stizostedion lucioperca (L. 1758)]. Bull. Eur. Ass. Fish Pathol. 12: 5-7

Olesen, N. J., Jorgensen, P. E. V. (1992). Comparative susceptibility of three fish cell lines to Egtved virus, the virus of viral haemorrhagic septicaemia (VHS). Dis. aquat. Org. 12: $235-237$

Olesen, N. J., Lorenzen, N., Jørgensen, P. E. V. (1991).

Responsible Subject Editor: F. M. Hetrick, College Park, Maryland, USA
Detection of rainbow trout antibody to Egtved virus by enzyme-linked immunosorbent assay (ELISA), immunofluorescence (IF), and plaque neutralization tests ( $50 \%$ PNT). Dis, aquat. Org. 10: $31-38$

Osadchaya, Y F., Nakonechnaya, M. G. (1981). Rhabdovirus salmonis, the cause of a new disease in rainbow trout (Salmo gälrdneri). J. Ichthyol. 21: 113-121

Reed, L. J., Muench, H. (1938). A simple method of estımating fifty percent end points. Am. J. Hygiene 27: 493-497

Sano, T. (1976). Viral diseases of cultured fishes in Japan. Fish Pathol. 10: 221-226

Wolf, K., Gravell, M., Malsberger, R. G. (1966). Lymphocystis virus: isolation and propagation in centrarchid fish cell lines. Science 151: 1004-1005

Wolf, K., Quimby, M. C. (1962). Established eurythermic line of fish cells in vitro. Science 135: 1065-1066

Wolf, K., Quimby, M. C. (1969). Fish cell and tissue culture. In: Hoar, W. S., Randall, D. J. (eds.) Fish physiology. Academic Press, New York, p. 253-305

Manuscript first received: December 28, 1992 Revised version accepted: May 25, 1993 


\section{Erratum}

Re: P. E. V. Jørgensen, N. J. Olesen, W. Ahne, T. Wahli, W. Meier

'Isolation of a previously undescribed rhabdovirus from pike Esox lucius'

Dis. aquat. Org. 16: 171-179 (1993)

- Fig. 2 on p. 175

Regrettably an incorrect version of the figure was published (along with the correct legend). The correct figure and legend appear below.

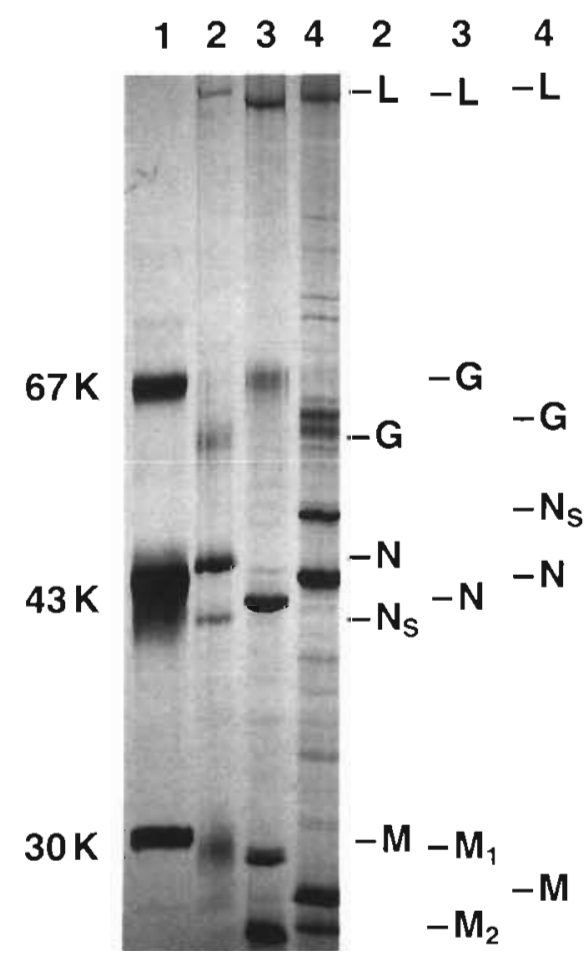

Fig. 2. Electropherogram of purified virus preparations in SDS-PAGE. Lane 1: Molecular weight markers; Lane 2: Eel rhabdovirus EVEX (vesiculo group); Lane 3: VHSV (lyssa group); Lane 4: DK 5533 from pike. The localization of the structural proteins $G, N_{S}, N$ and $M$ (Lanes 2 and 4 ) and $G, N$ $M_{1}$ and $M_{2}$ (Lane 3), respectively, is indicated The protein band of about $22 \mathrm{kD}$ in Lane 4 is considered to be a degradation product of the $M$ protein, since it appeared only after prolonged storage of the purified virus 